\title{
Papomono mine modelled as an inclined cave
}

\author{
D Villa Dassault Systèmes, Canada
}

J Baraqui Minera Tres Valles, Chile

S Maass Minera Tres Valles, Chile

\begin{abstract}
For a low-grade deposit with low rock mass quality, the inclined caving method is a feasible option, representing a low-cost, high-productivity and flexible alternative for a complexly shaped orebody. After performing a number of analyses of the trade-offs between block caving, sub-level caving, sub-level stoping, etc. at its Papomono mine, Minera Tres Valles (MTV) opted for inclined caving due to the orebody's geometry and the geotechnical conditions (low rock quality). This method permits optimisation of the development effort, increasing production and reducing operating costs and dilution. This paper examines the inclined caving model created using PCBC software, describing the overall process used to estimate reserves and the production schedule, including the inputs used as mine sequence, drawpoint commissioning and production rate, etc. as related to an operation of this type.
\end{abstract}

\section{Introduction}

MTV is located in the south of the Coquimbo Region in central Chile (Figure 1). The main access to MTV is from Road D-81, which connects the towns of Illapel and Salamanca. The operation is $222 \mathrm{~km}$ north off Highway 5 from Santiago to Los Vilos (Minera Tres Valles 2018).
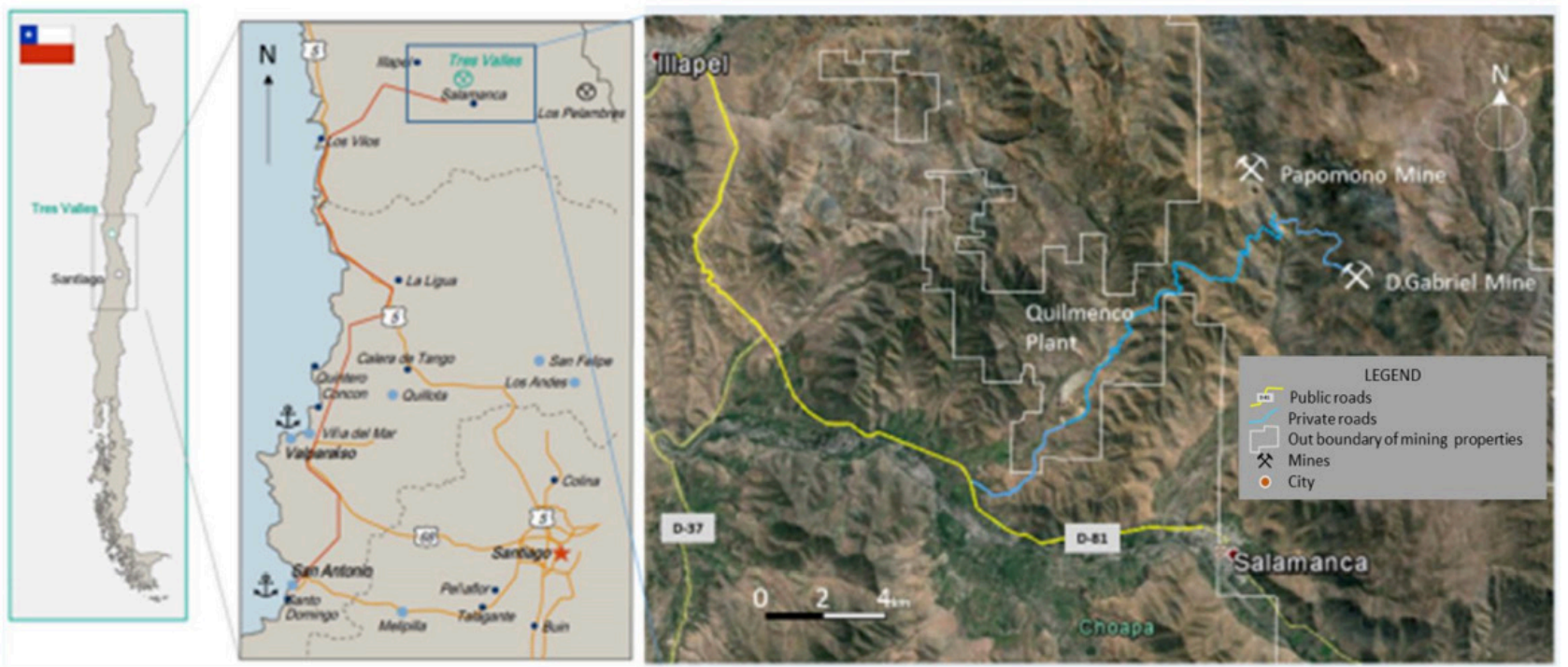

Figure 1 MTV location

The stratigraphy observed in the Papomono deposit consists mainly of a sequence of andesite interbedded with pyroclastic rocks of the Quebrada Marquesa Formation, N40 $\mathrm{W}$ strike, dipping $15^{\circ}$ to the SW (Minera Tres Valles 2018). Figure 2 shows that the lithostratigraphy used for deposit modelling purposes, formed by the Papomono Fault Zone and three main levels from top to base:

- Unit C: Volcanic breccias and lapillis intercalated with andesitic lava and commonly epidotised. This is the most common outcropping unit and presents a small amount of mineralisation. 
- Unit B: Porphyritic and compact andesite, which is considered a physical barrier for the ascendant fluids.

- Unit A: Volcanic units (ash and lapilli tuffs with some andesites). This unit is the main host rock in Papomono.

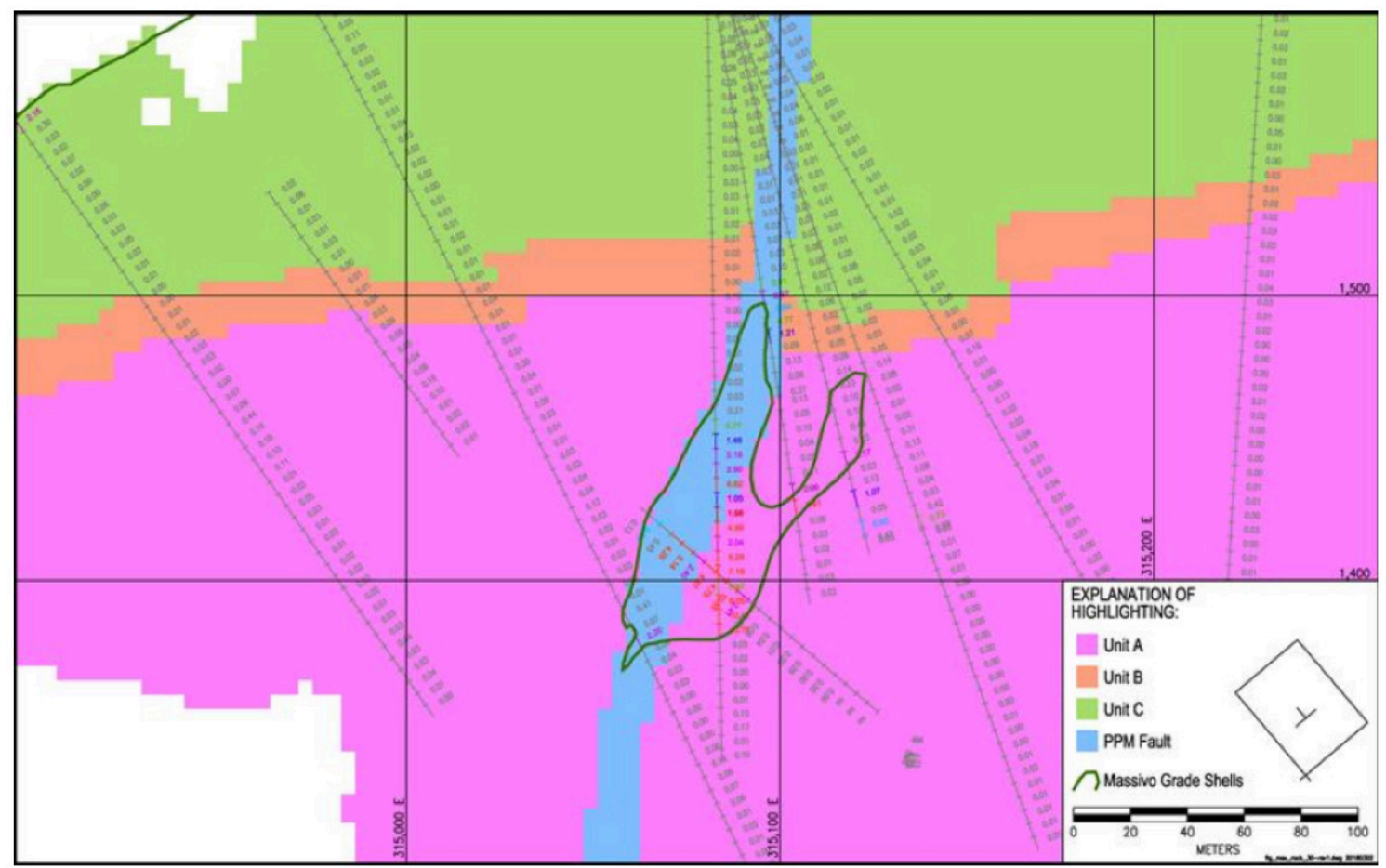

Figure 2 Massive deposit - rock types and grade shells

The orebody was modelled considering two main controls: structural (related to the Papomono Fault Zone) and the stratabound deposits (mantos). The final model was generated by combining both (Figure 3). The orebody is $450 \mathrm{~m}$ along strike and around $80 \mathrm{~m}$ wide. The wider zones are in the southern half of the orebody, measuring up to $110 \mathrm{~m} \mathrm{~W}$-E, reflecting an important concentration of thick mantos in this zone (Minera Tres Valles 2018).

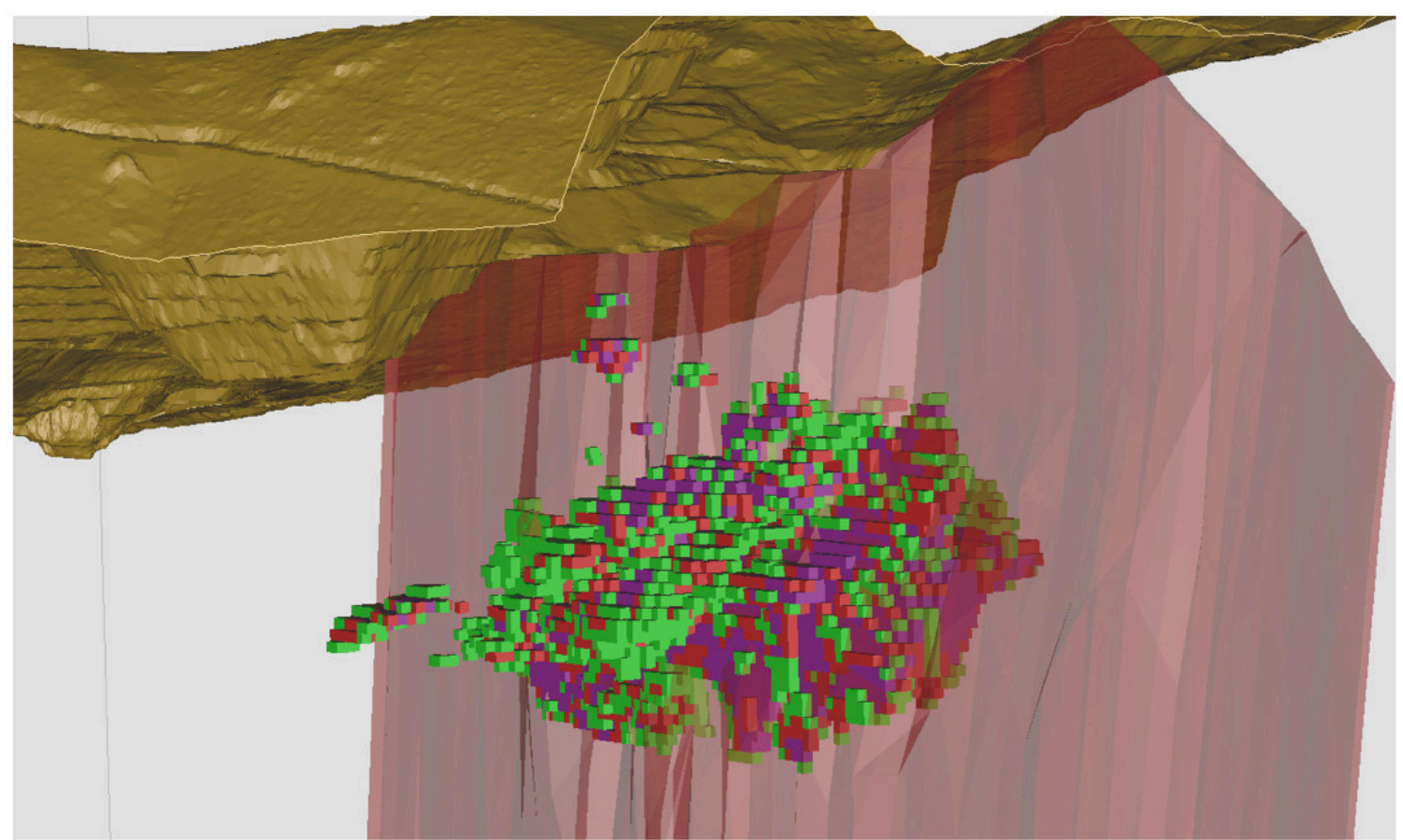

Figure 3 Orebody modelling combining mineralisation from the Papomono Fault Zone and the stratabound deposits (mantos) 
A summary of the rock mass classification, based on the above description of the geological units, is shown in Table 1. Low rock mass competence is observed inside the PPM Fault and the Mantos Zone (30 and 39 , respectively).

Table 1 Summary of rock mass classification

\begin{tabular}{|c|c|c|c|c|c|c|c|c|c|}
\hline & \multicolumn{3}{|c|}{ Inside PPM Fault } & \multicolumn{3}{c|}{ Outside PPM Fault } & \multicolumn{3}{c|}{ Inside Mantos Zone } \\
\hline & Q & RMR89 & RMRL & Q & RMR89 & RMRL & Q & RMR89 & RMRL \\
\hline Min Value & 0.03 & 29 & 21 & 0.02 & 35 & 25 & 0.07 & 33 & 24 \\
\hline Median & 1.85 & 41 & 29 & 1.73 & 51 & 38 & 1.8 & 50 & 37 \\
\hline Max Value & 15.83 & 59 & 47 & 17.64 & 81 & 85 & 9.3 & 72 & 67 \\
\hline Mean & 2.27 & 42 & 30 & 2.28 & 52 & 40 & 2.15 & 51 & 39 \\
\hline Std deviation & 1.96 & 6.2 & 5.2 & 2.06 & 7 & 8 & 1.56 & 7.6 & 8 \\
\hline Variance & 3.86 & 37.8 & 26.6 & 4.24 & 49 & 64.2 & 2.45 & 57.6 & 63.7 \\
\hline
\end{tabular}

\section{$2 \quad$ Inclined caving}

Inclined caving is a variant of block caving that is more suitable depending on the orebody geometry and/ or ground conditions. The term "inclined caving layout" is used to describe the mining configuration in which rows of drawpoints are offset vertically and follow an inclined plane (Jakubec \& Laubscher 2012).

The inclined layout was modelled and compared with other options for the Papomono mine. It was selected as a feasible and economically viable alternative.

The advantages of the inclined cave layout used at Papomono mine include:

- Suitability for ore zone shape and grade distribution;

- Stronger layout and more effective ground support, minimising the volume of excavations inside the orebody, mainly at the PPM Fault;

- Lowest cost and higher productivity compared with other UG alternatives;

- More efficient ore extraction and draw control due to an independent drawpoint per extraction tunnel;

- Layout flexibility offering the option of brow repairs and possible brow retreat and reestablishment of the new brow without affecting LHD loading performance;

- Increase in mineable reserves, reducing the extraction of waste in the bottom part of the draw column by adjusting its location to maximise ore recovery at low cost.

Compared with horizontal block caving, inclined caving is less popular. However, several past inclined layout operations and new projects currently being developed offer experience in use of the method.

\section{$2.1 \quad$ Operations}

- Gaths Mine (Zimbabwe). The moderately competent and moderately weak rock mass (UCS 3070MPa, 80\% IRMR 40-60) of this operation included minor shear zones and inclined caving successfully replaced the failing horizontal caving layout. With a production rate of 2,000 tpd, the mine has been in production for over 40 years (Jakubec \& Laubscher 2012).

- Bell Mine (Canada). The orebody of this mine was moderately competent, with an IRMR of 45 to 65. Production was approximately 5,000 tpd (Jakubec \& Laubscher 2012).

- Shabanie Mine (Zimbabwe). A truncated SLC layout was used with an undercutting sequence from top to bottom to ensure the correct hydraulic radius for cave propagation, allowing for stress relief cover over the upper footwall drifts (Laubscher \& Jakubec 2000). 
- Cassiar Mine (Canada). The footwall inclined cave layout was developed at this mine in 19901992 (Figure 4). It had extremely weak and mainly poor-quality rock mass, with an estimated rock mass strength of 1-5 MPa and an IRMR of mainly 15-25. The mine had a production rate of some 3,000 tpd from about 10-12 drawpoints (Jakubec \& Laubscher 2012).

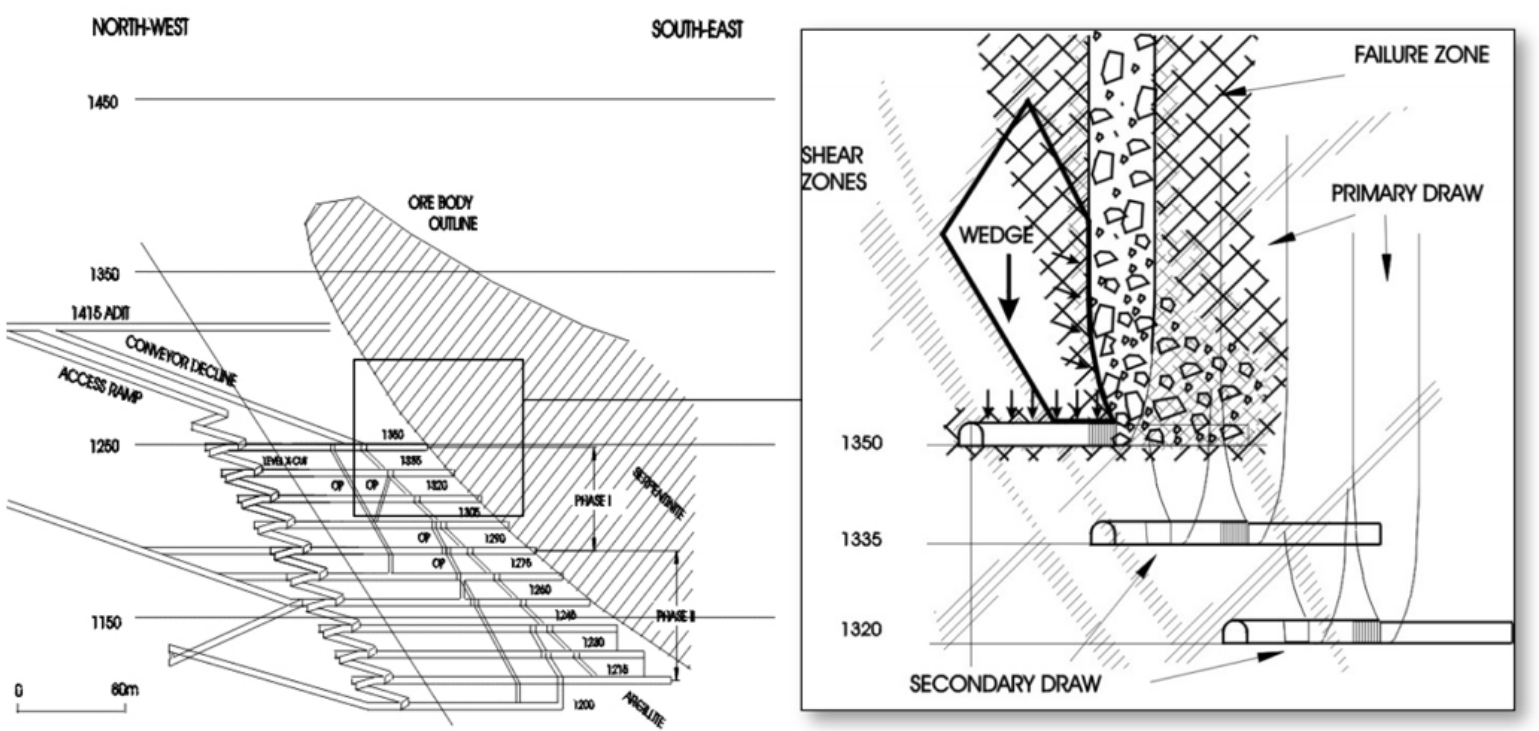

Figure 4 Footwall layout example from the Cassiar Mine (Jakubec \& Laubscher 2012)

- Ekati (Canada). Four production levels with 20-m vertical spacing are currently in operation (Figure 5). Inclined caving improved the recovery of the Koala pipe (Fuykschot \& Loewen 2016).

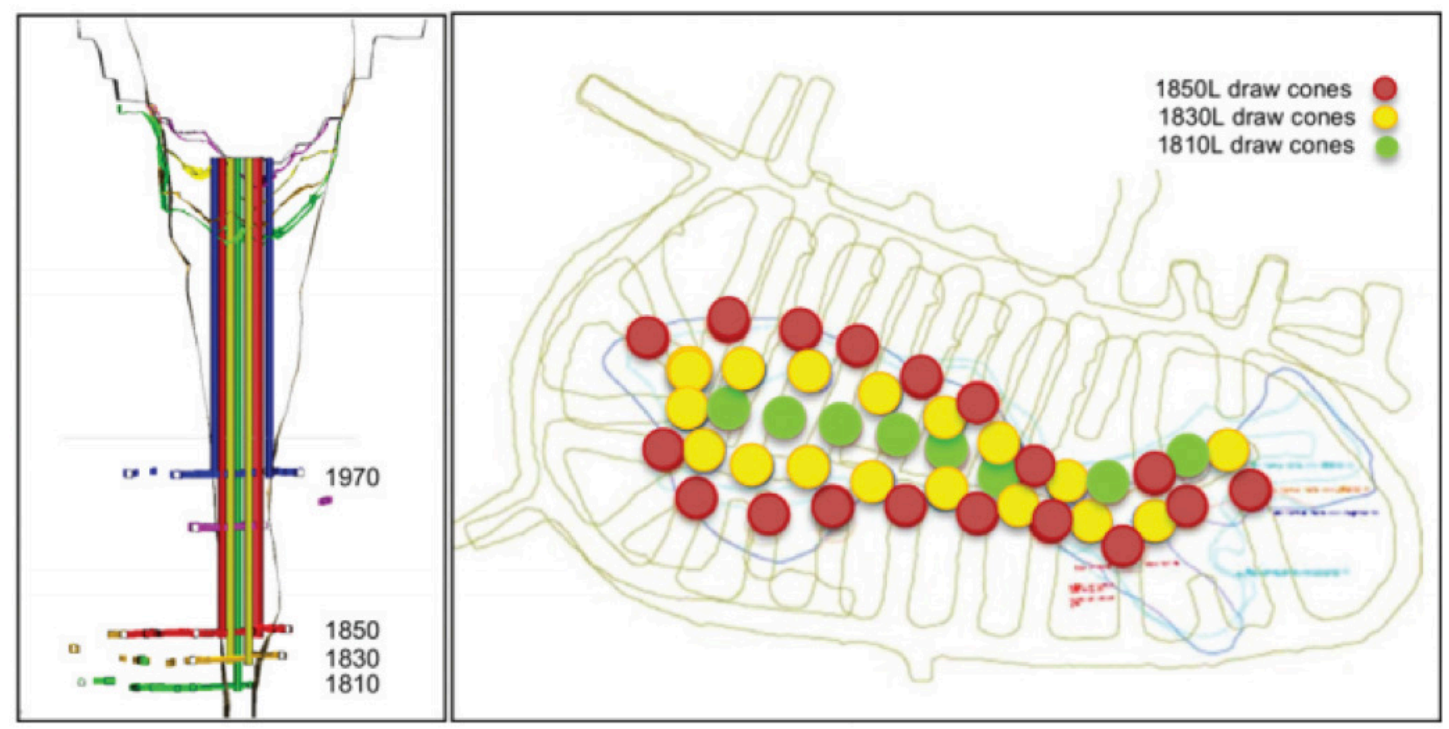

Figure 5 Inclined cave at the Ekati Mine (Fuykschot \& Loewen 2016)

\subsection{Projects}

- Block 5, Finsch Diamond Mine (South Africa). Feasibility-study level. The considerations taken into account included higher in-situ stresses due to depth, poor rock conditions (RMR 35-55) and the stability of the extraction level. An isometric view is shown in Figure 6 (Mthombeni \& Paucar 2004). 


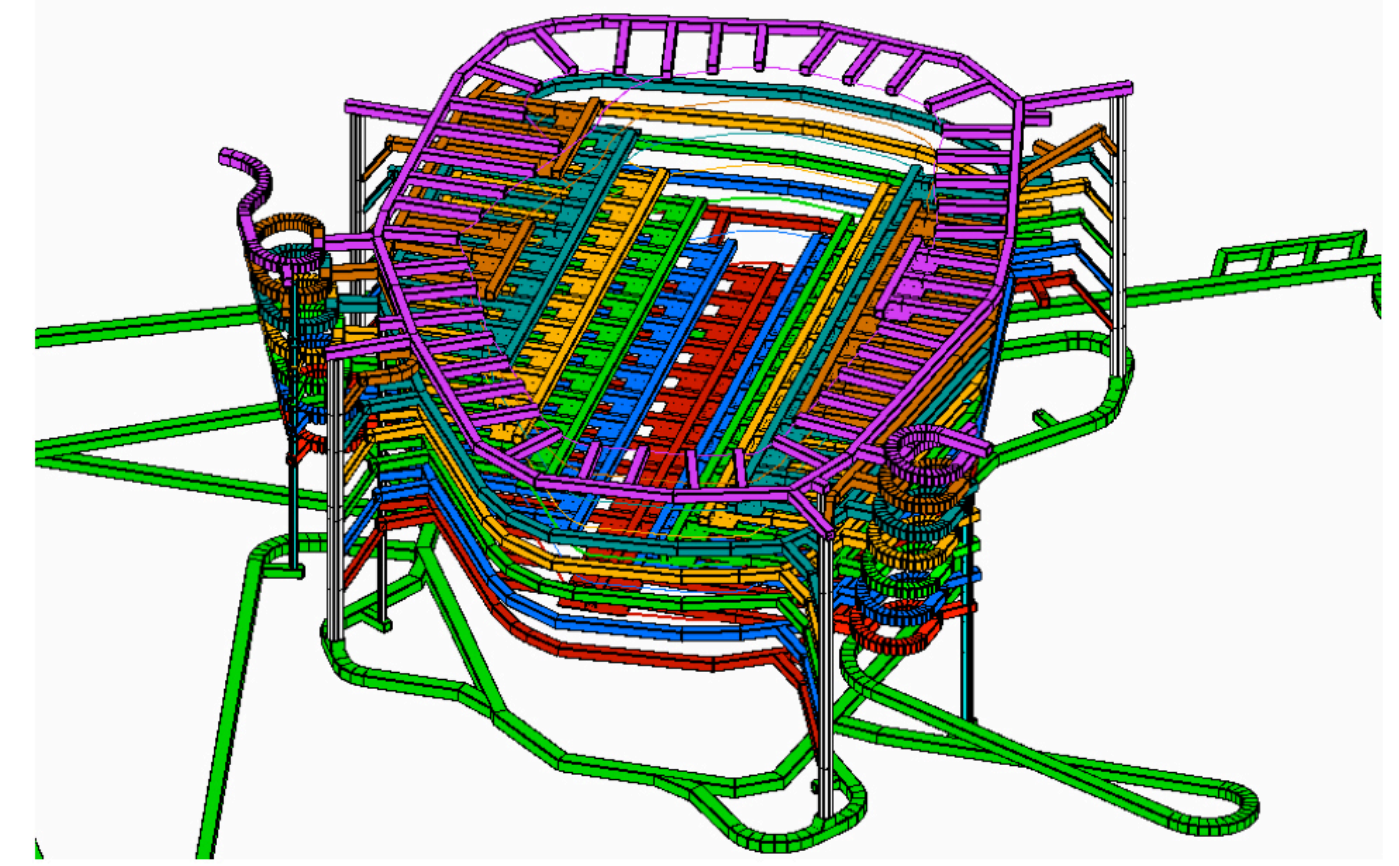

Figure 6 Isometric view of Block 5, Finsch Diamond Mine (Mthombeni \& Paucar 2004)

- Ernest Henry Mine (Australia). Conceptual level study. The inclined orebody dips $45^{\circ}$ and continues from the bottom of the open pit down to approximately $1,000 \mathrm{~m}$. The very strong and competent orebody (IRMR 65-75) has a thickness of up to $200 \mathrm{~m}$. Inclined caving was considered mainly because of the inclined orebody geometry and the expected high secondary breakage. However, due to caveability and fragmentation risk, SLC was selected instead (Jakubec \& Laubscher 2012).

- 500 orebody, Mt. Isa Mine (Australia). Scoping level study. The main reasons for considering an inclined cave layout were the inclined orebody F/W geometry, poor ground conditions (IRMR 20-40) and reactive ore. Due to its economics and the perceived risk, the 500 orebody is not currently being considered for mining (Jakubec \& Laubscher 2012).

- La Encantada (Mexico). Preliminary UG method selection study. The deposit has low rock mass competence (MRMR 21-34) and, with its planned production rate of 2,000 tpd limited by plant capacity, an expansion is being evaluated (Valencia et al. 2014) (Figure 7).

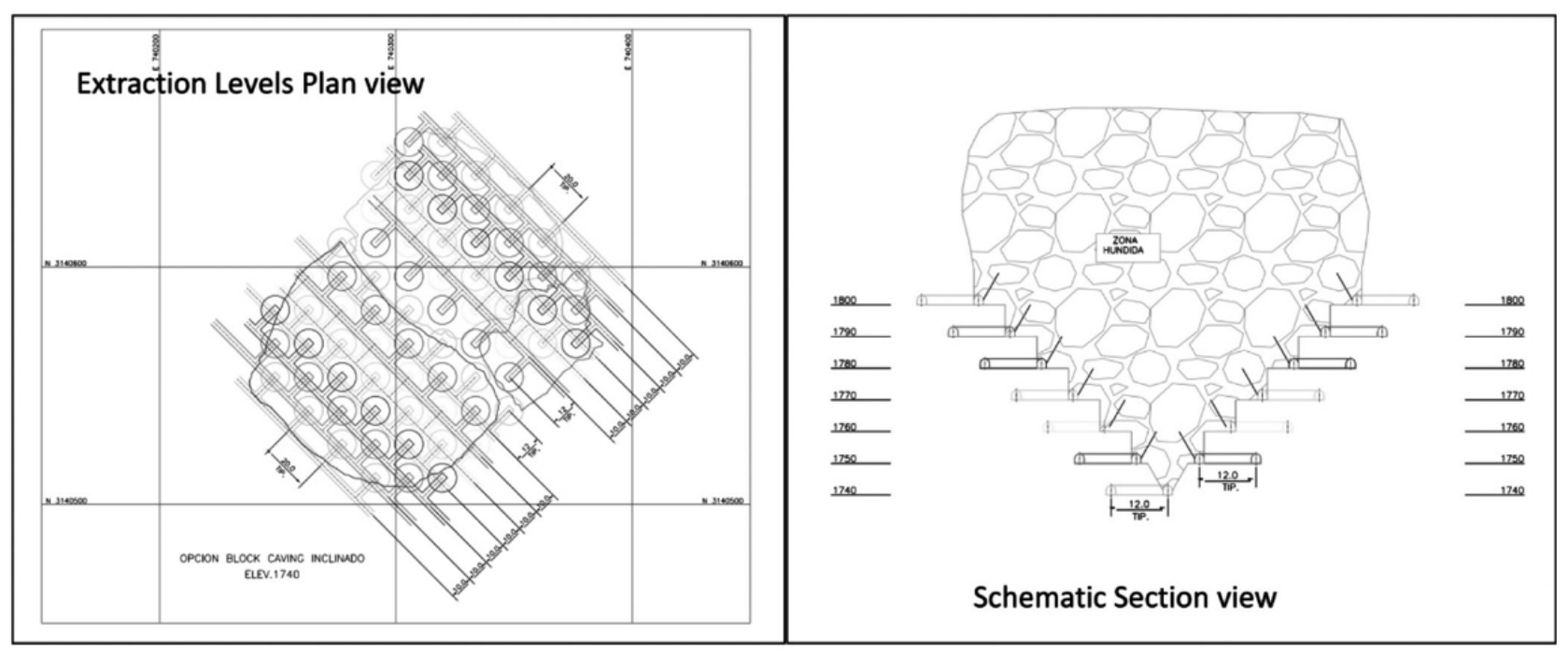

Figure 7 Inclined cave layout at La Encantada (Valencia et al. 2014) 
- DNK mine (Kazakhstan). Conceptual level study. The poor ground condition encountered at DNK (IRMR 20-50) and plugging and/or dipping medium-to-thick orebodies suggested the design of a $V$-shaped layout with $20 \mathrm{~m}$ between levels and 12-m tunnel spacing. An isometric view is shown in Figure 8 (Fuykschot \& Loewen 2016).
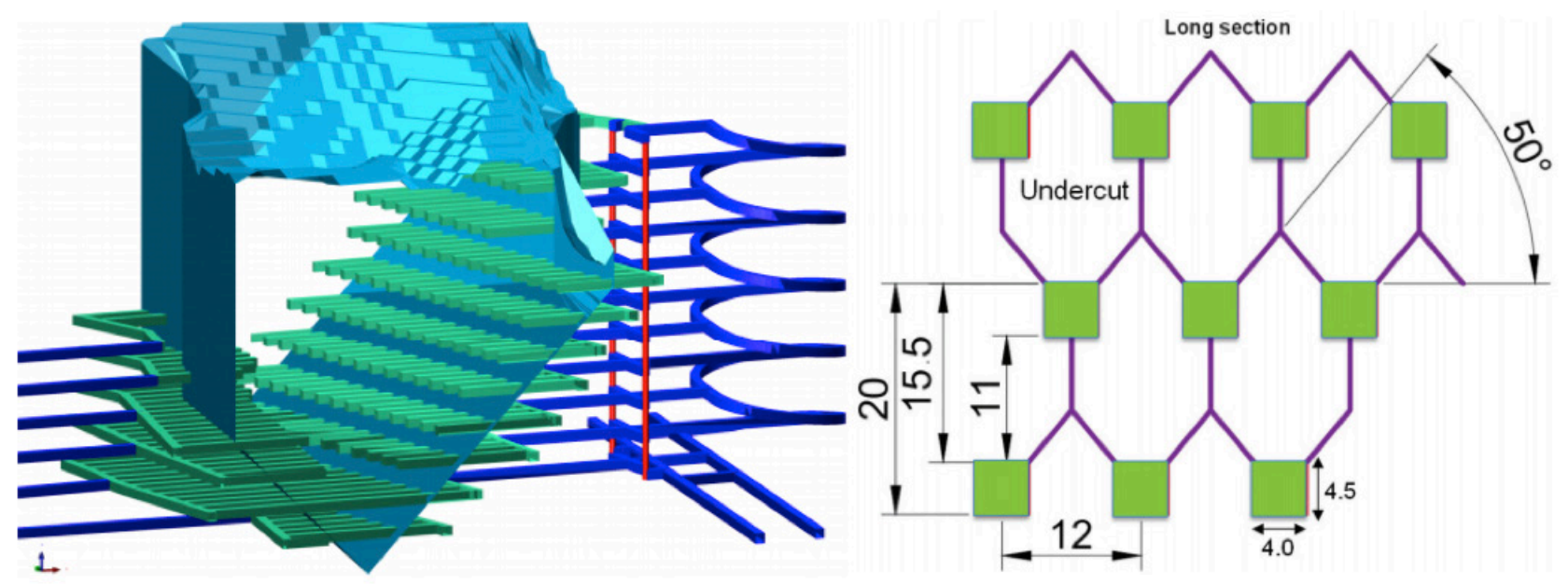

Figure 8 Isometric view of inclined cave layout at DNK Mine (Fuykschot \& Loewen 2016)

\section{$3 \quad$ PCBC model}

Different layout options were evaluated, initially using Footprint Finder (Villa 2014) to identify the best elevation and shape for an inclined layout. The orebody has an irregular shape, with the bottom part located $300 \mathrm{~m}$ below the topography and an economic height of draw of approximately $130 \mathrm{~m}$. One of the $\mathrm{V}$-shaped alternatives analysed during the prefeasibility study is shown in Figure 9 where the block model for $\mathrm{Cu}$ is displayed with high grade using warm colours and low grade with cold colours.

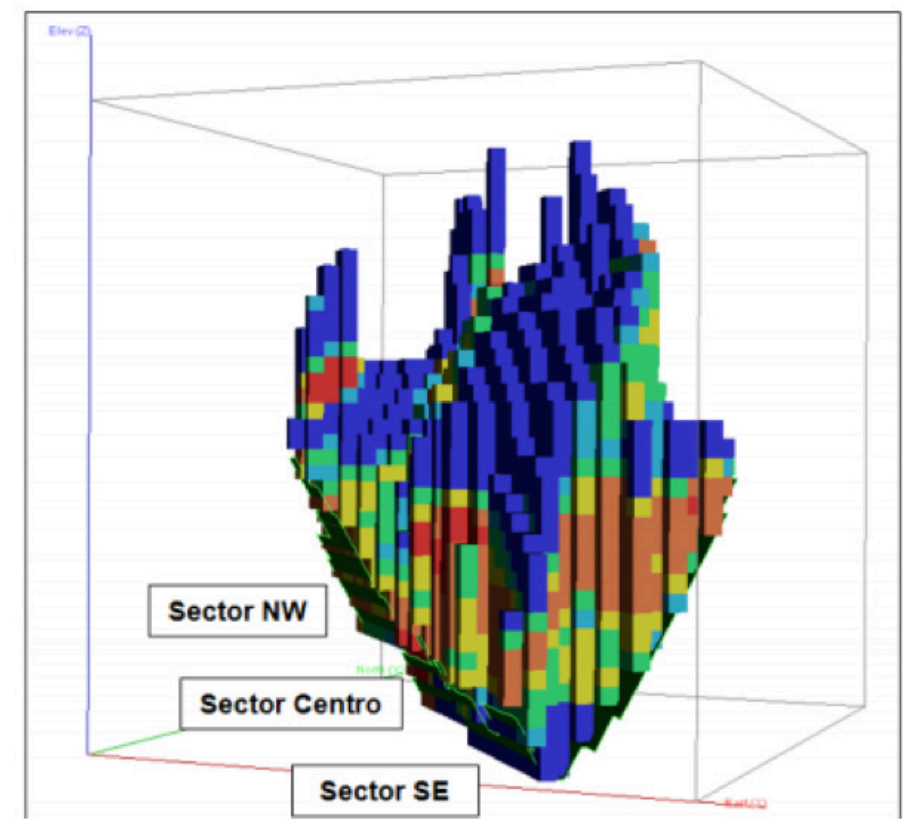

Figure 9 Footprint Finder results (Prefeasibility Study 2018)

Several layout alternatives were also evaluated to understand drawpoint distribution, ore recovery, the project's economics and pillar stability. Finally, the option selected was a design with four levels and 97 drawpoints based on 13-m horizontal drawpoint spacing and a vertical distance of $11 \mathrm{~m}$ between levels. 3D and 2D views of the mine layout and drawpoint distribution are shown in Figures 10 and 11. 


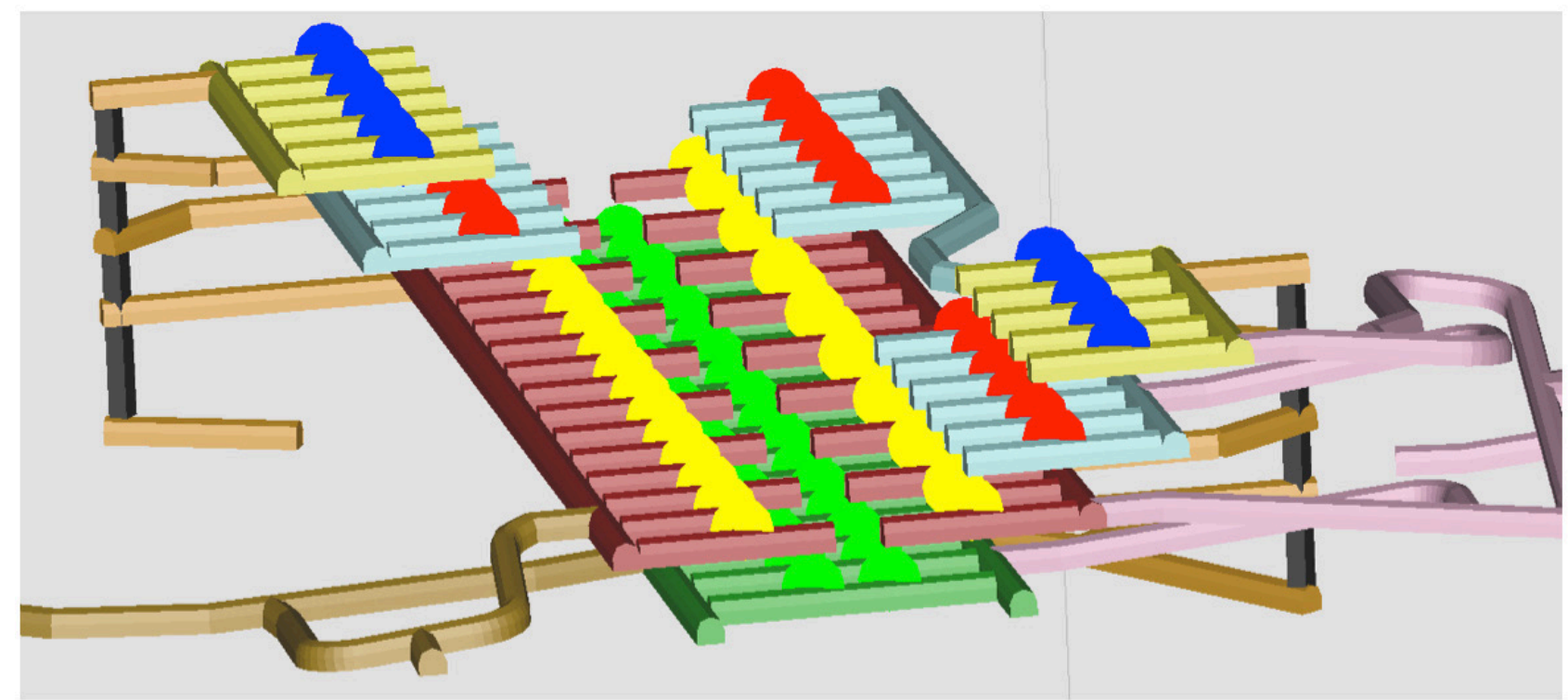

Figure 10 3D view of mine layout

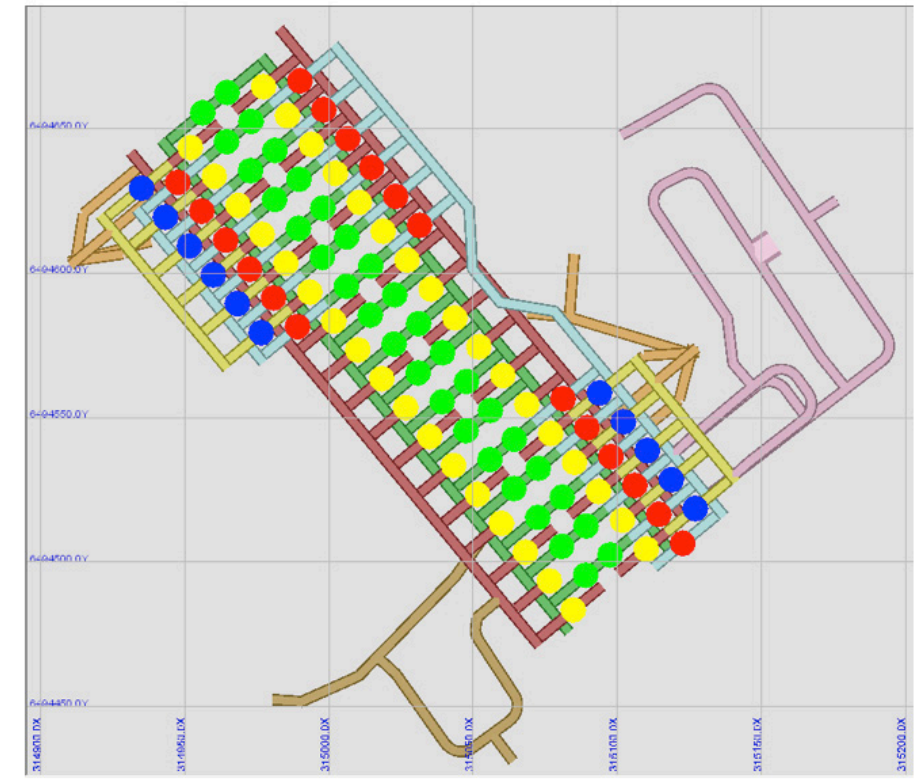

Figure 11 2D view of mine layout and drawpoint distribution

\subsection{Draw cone geometry}

The rock mass classification (Table 1) and Laubscher's abaqus for drawpoint spacing (Figure 12) suggested a maximum spacing of $13 \mathrm{~m}$ and an isolated diameter of $9 \mathrm{~m}$. This information was used to create a draw cone geometry in PCBC (Diering 2000) that permitted good interaction between drawpoints at different levels. The grade distribution is shown in Figure 13 where it can be seen that the drawpoint distribution is able to capture the high grade properly. 


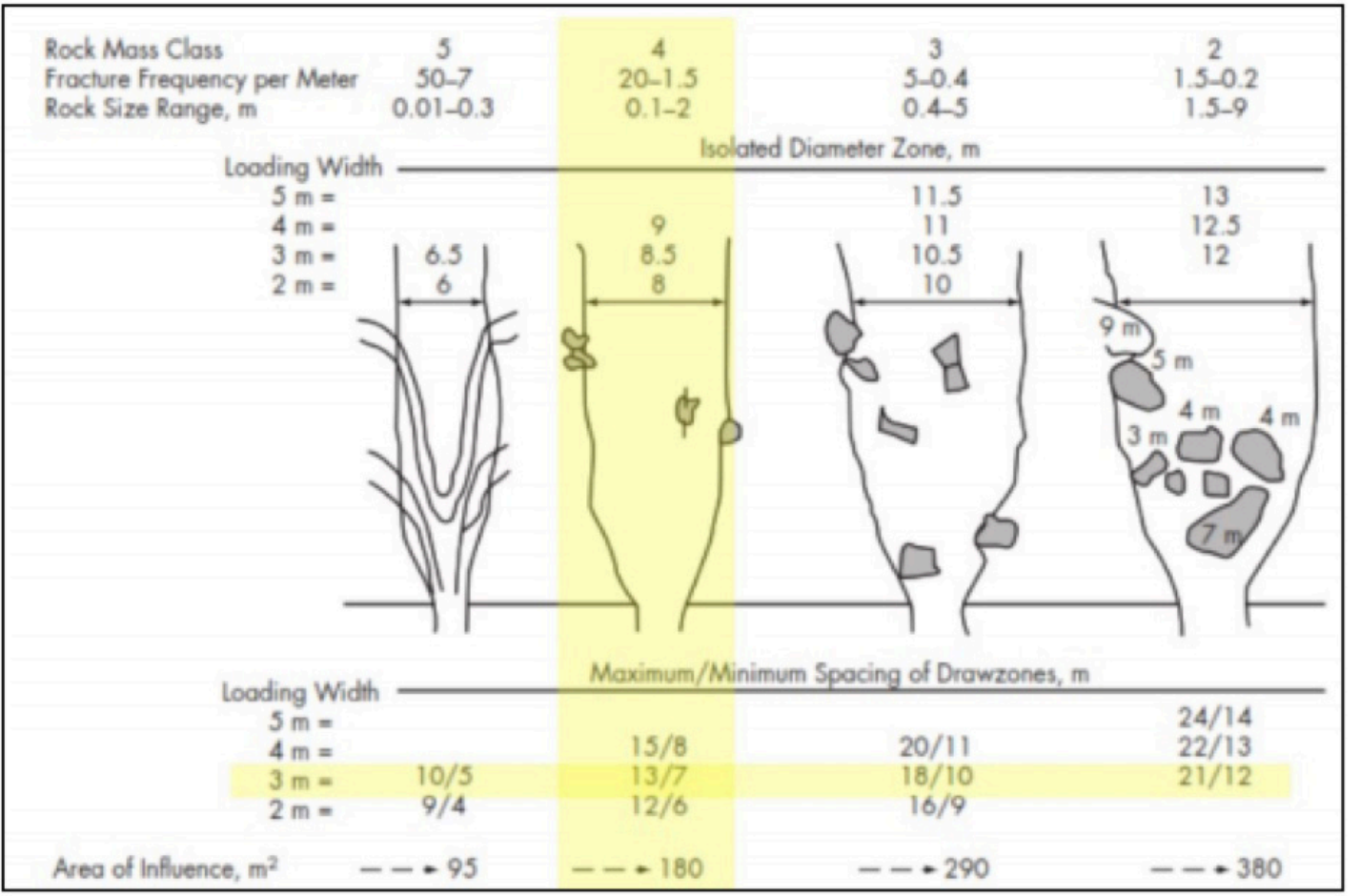

Figure 12 Laubscher's abaqus for drawpoint spacing (Laubscher 1994)

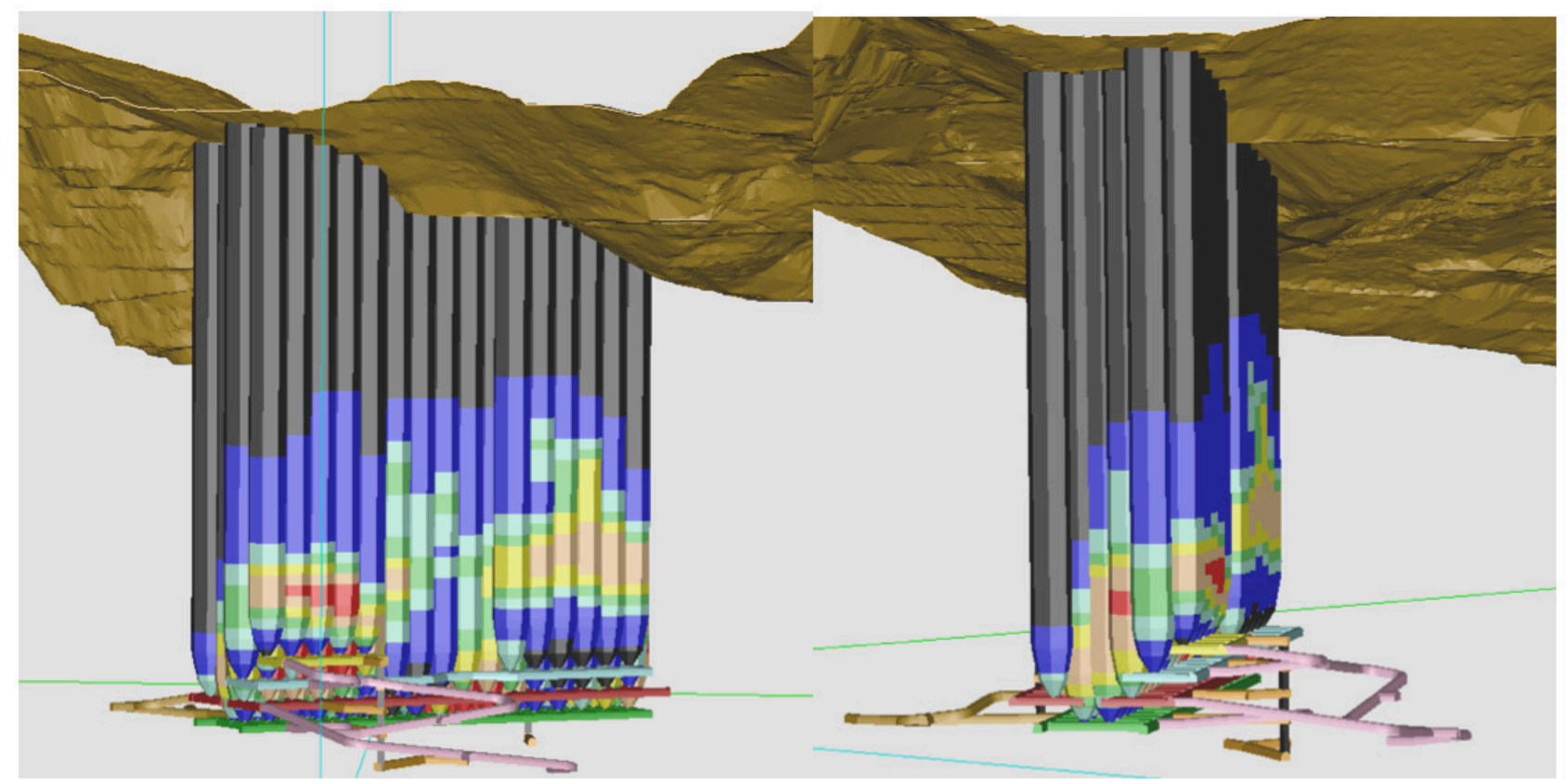

Figure 13 Draw cone geometry in PCBC

\subsection{Mine sequence for drawpoint opening}

The Papomono mine uses a bottom-up caving direction, with undercutting and caving beginning at the lower levels, progressing upward and moving from north to south. An average of four drawpoints are commissioned per month and the entire layout is opened in two years (see Figure 14 for drawpoints opened per month). 
The critical hydraulic radius for initiating caving based on the Papomono rock mass (MRMR=20) was estimated at 9. This does not differ from a horizontal block cave, but the sequence is key to initiating and controlling cave propagation without affecting the quality of extraction and the stability of the upper levels.

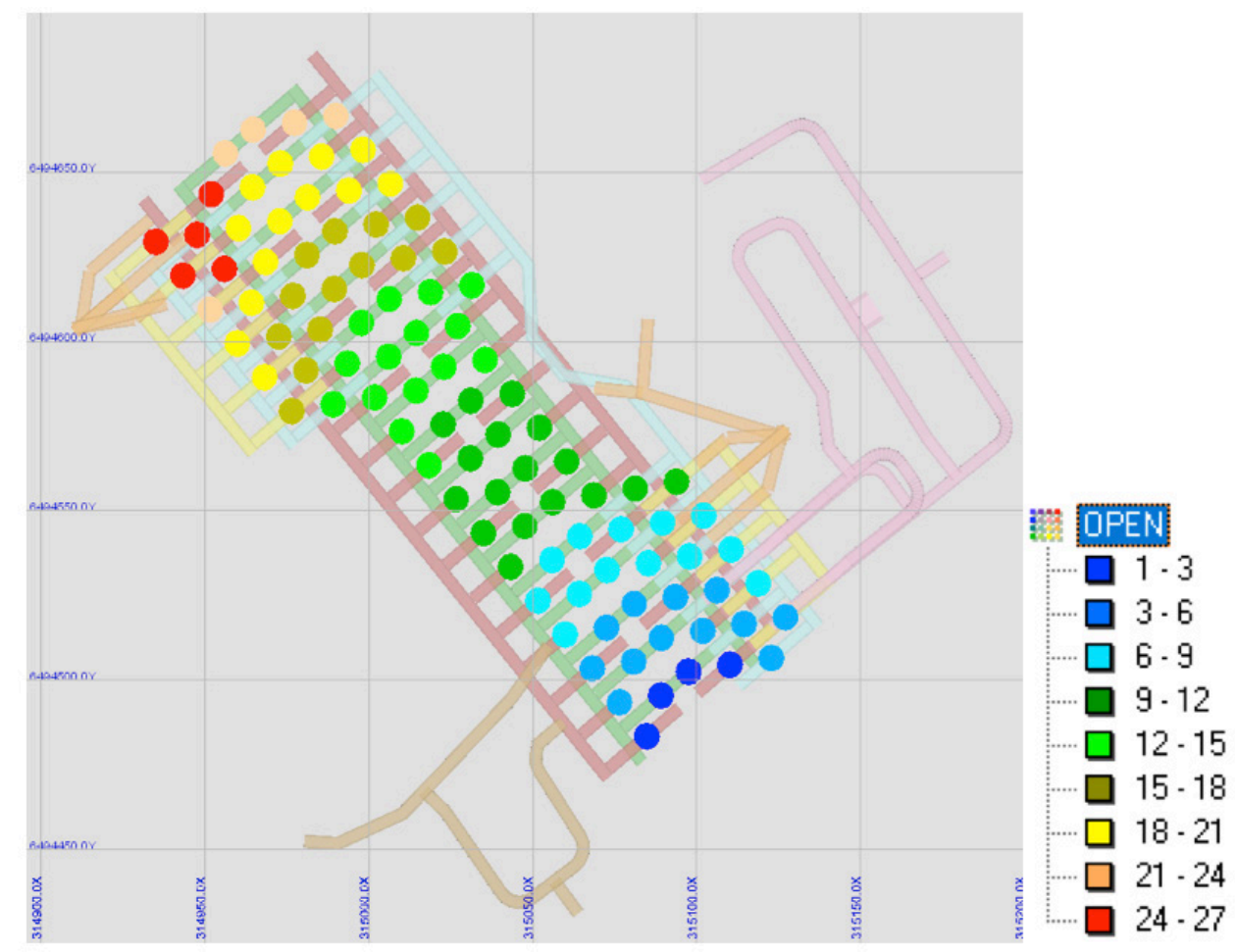

Figure 14 Mine sequence - drawpoints opened per month

\subsection{Production schedule: base case}

Planning and operational experience at other mines recommended a maximum extraction rate of $0.25 \mathrm{t} / \mathrm{m}^{2}$-day, even though inclined caving permits more efficient ore extraction, given the independent drawpoints where mucking, secondary blasting and/or repairs can be carried out without interfering with production in neighbouring drawpoints. Extraction at Papomono will be limited by geotechnical constraints and the need to maintain good draw control in order to ensure positive result in terms of caveability and ore recovery. This will be key due to the complexity of the orebody share and grade distribution.

The base case was created targeting a production rate of 2,000 tpd, which was reached in month 15 and maintained for three years. Figure 15 shows the base case production schedule per month. Reserves were calculated to be $2.68 \mathrm{Mt}$ at $1.22 \%$ of recoverable $\mathrm{Cu}$. 


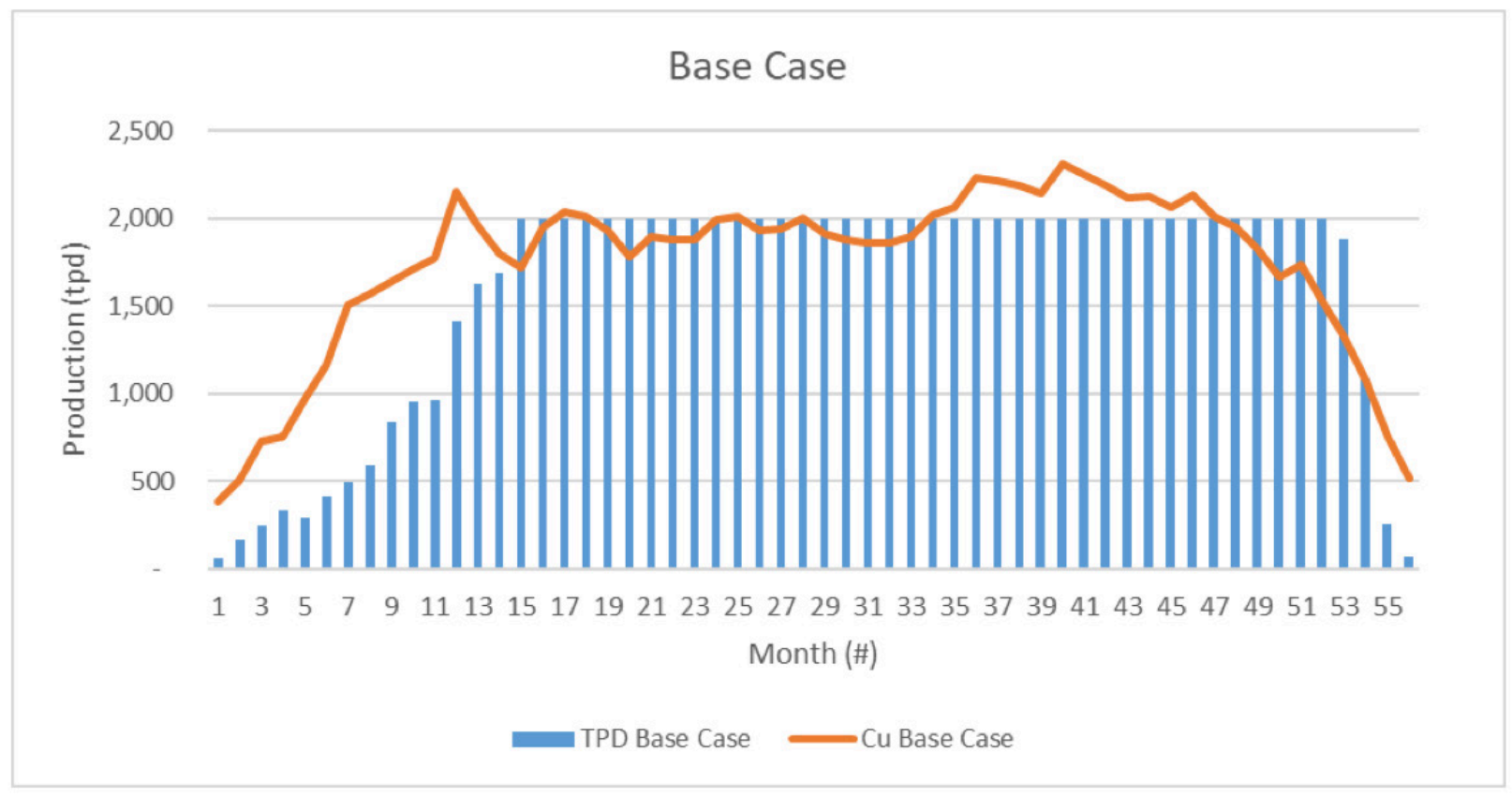

Figure 15 Base case production schedule

The material handling system is designed to operate with 3.5-yd $\mathrm{d}^{3} \mathrm{LHD}$ equipment, transporting ore from the drawpoints to ore passes located on the east and west sides. The ore passes discharge the ore directly to the floor of a crosscut from which, by means of a frontal loader, the 30 -tonne trucks that haul the ore from the mine to the plant are loaded (Prefeasibility Study 2018).

\subsection{Production schedule: ore and waste handled separately}

In some drawpoints, the initial part of the column has a low grade or simply dilution (Figure 16) and, in these cases, there is the option to plan and extract ore and dilution separately. PCBC offers the option of managing this, using multiple constraints associated WITH the quality of the ore and solved by quadratic programming. An additional run was carried out, planning to handle a maximum of 200 tpd of waste and 2,000 tpd of ore separately.

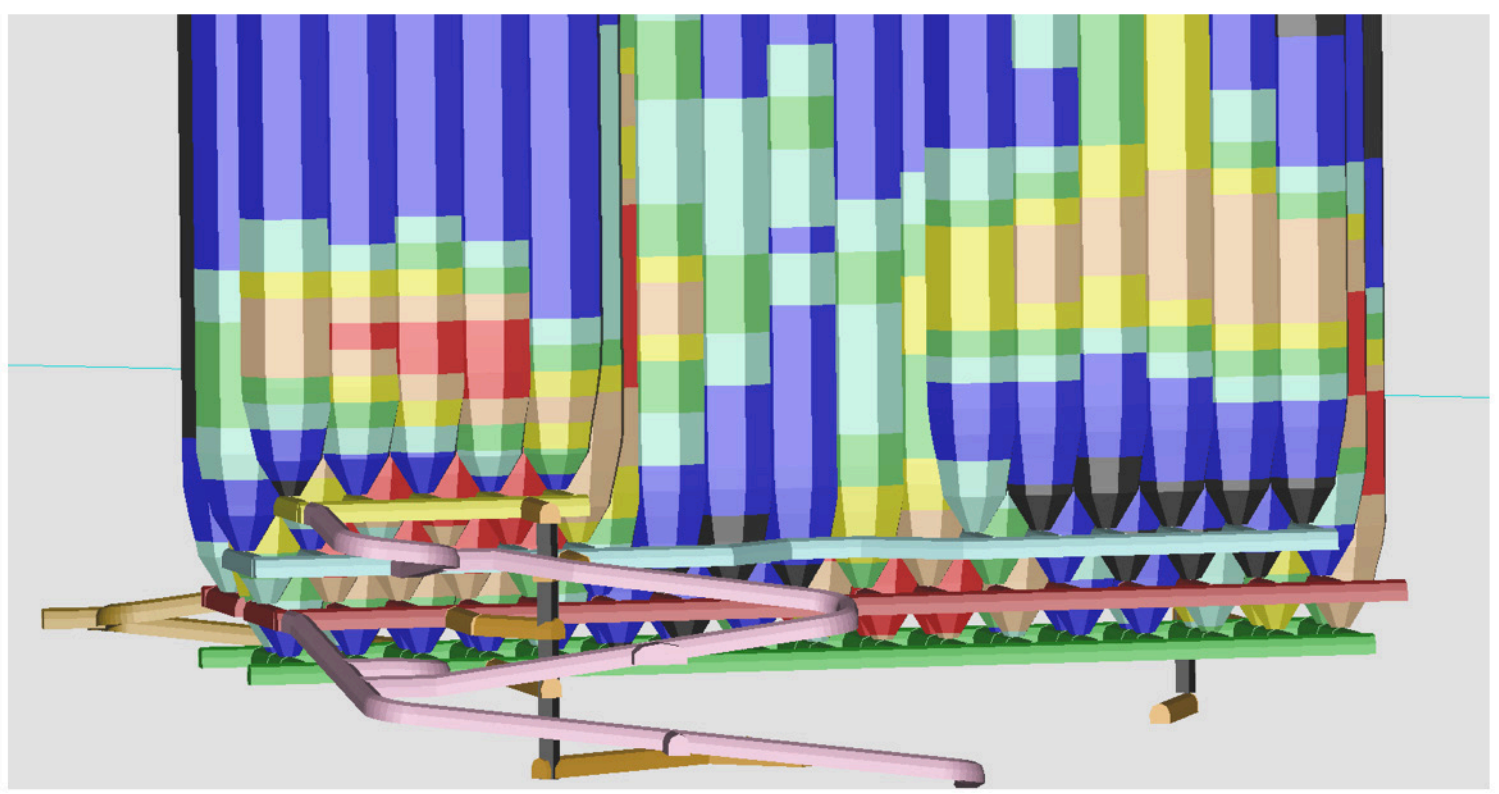

Figure 16 Draw columns coloured by Cu grade 
Figures 17 and 18 show the result of the production schedule. The reserve calculated in this case was $2.54 \mathrm{Mt}$ at $1.30 \%$ of recoverable $\mathrm{Cu}$. These results represent $5 \%$ less tonnage but $0.3 \%$ more metal compared with the base case.

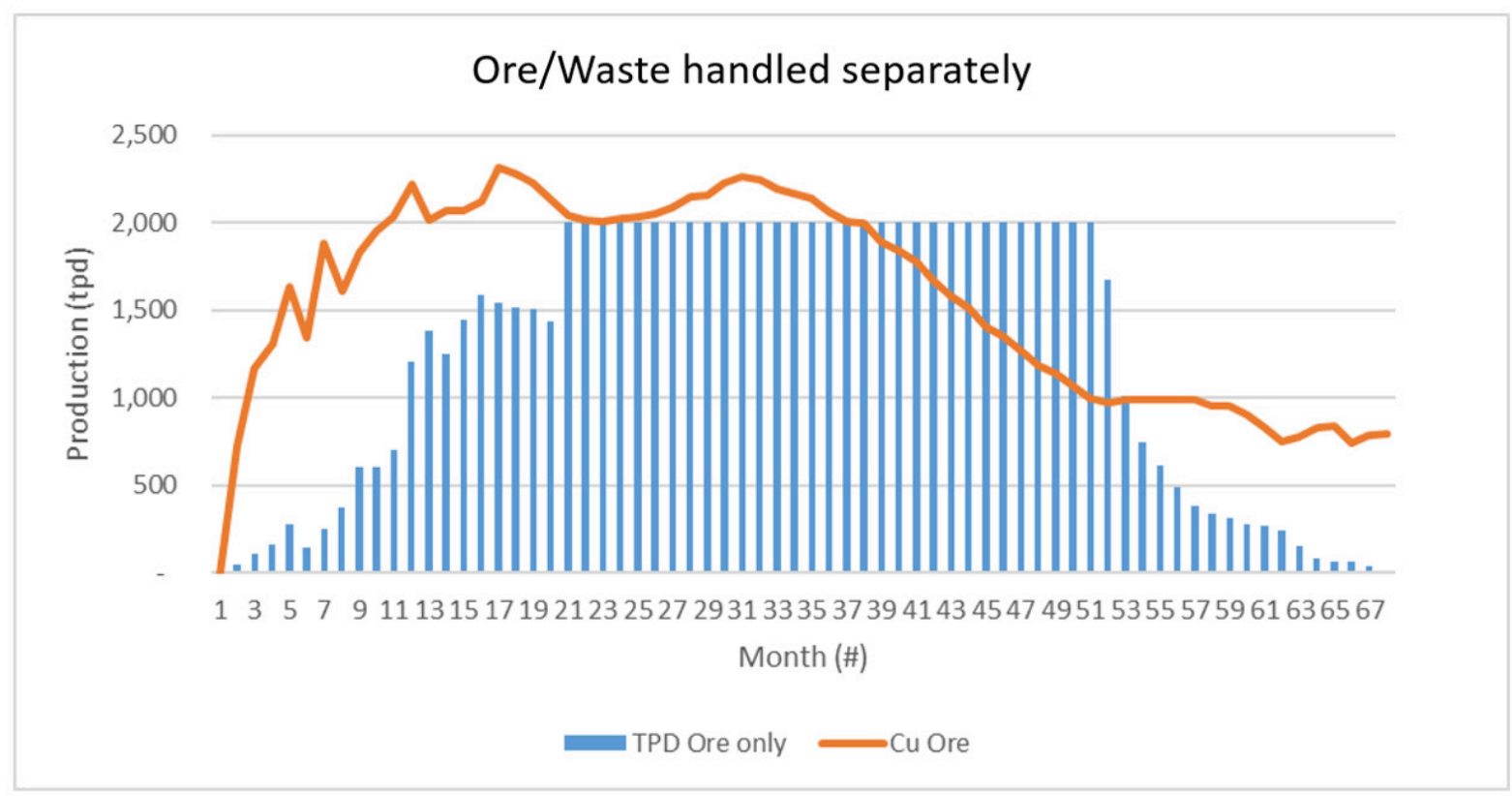

Figure 17 Production schedule reporting only ore

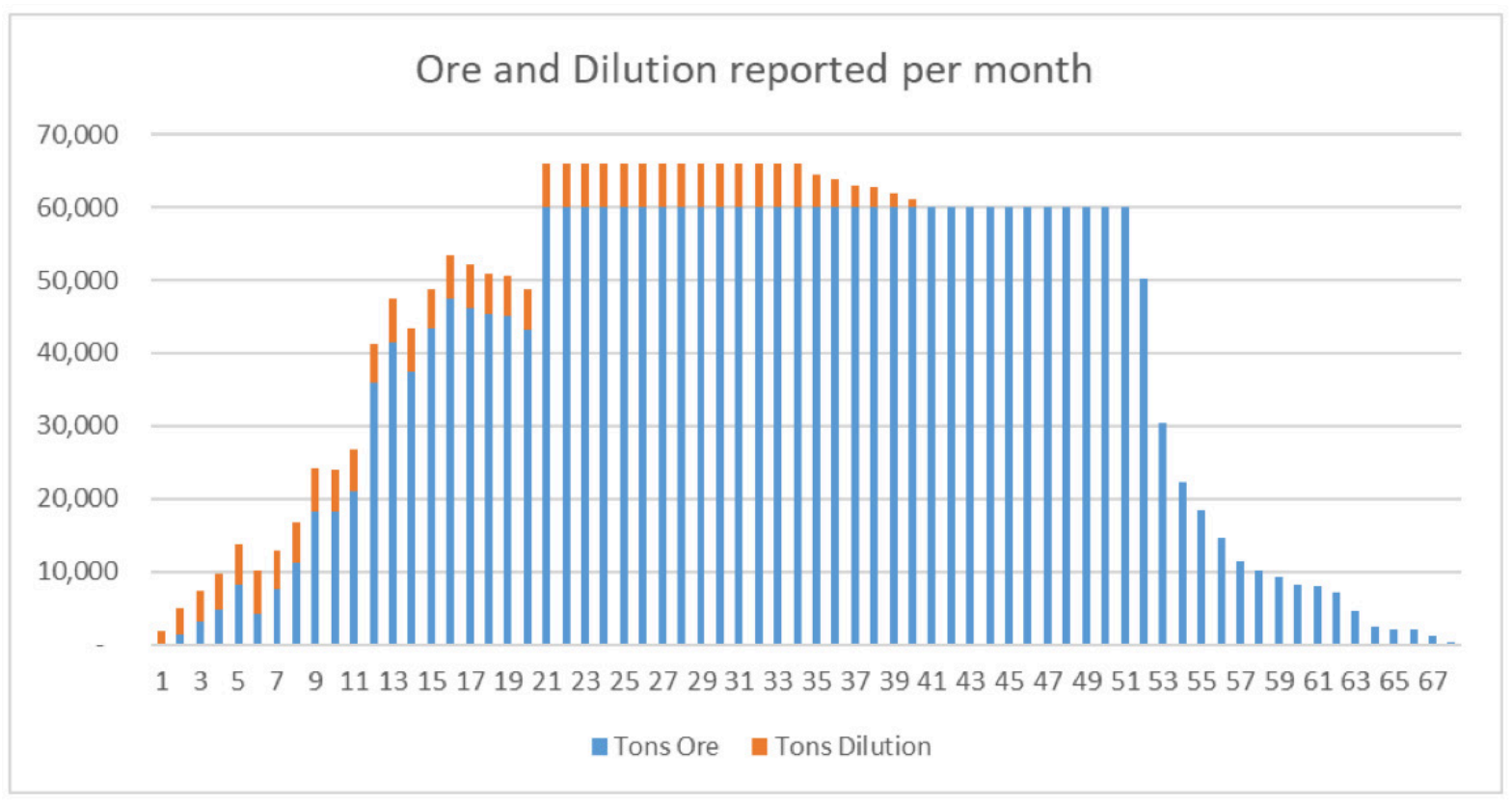

Figure 18 Tonnage reporting ore and dilution separately

Compared with the base case, the separate handling of ore and dilution increases the grade sent to the mill by 30\% during the first 39 months (Figure 19). 


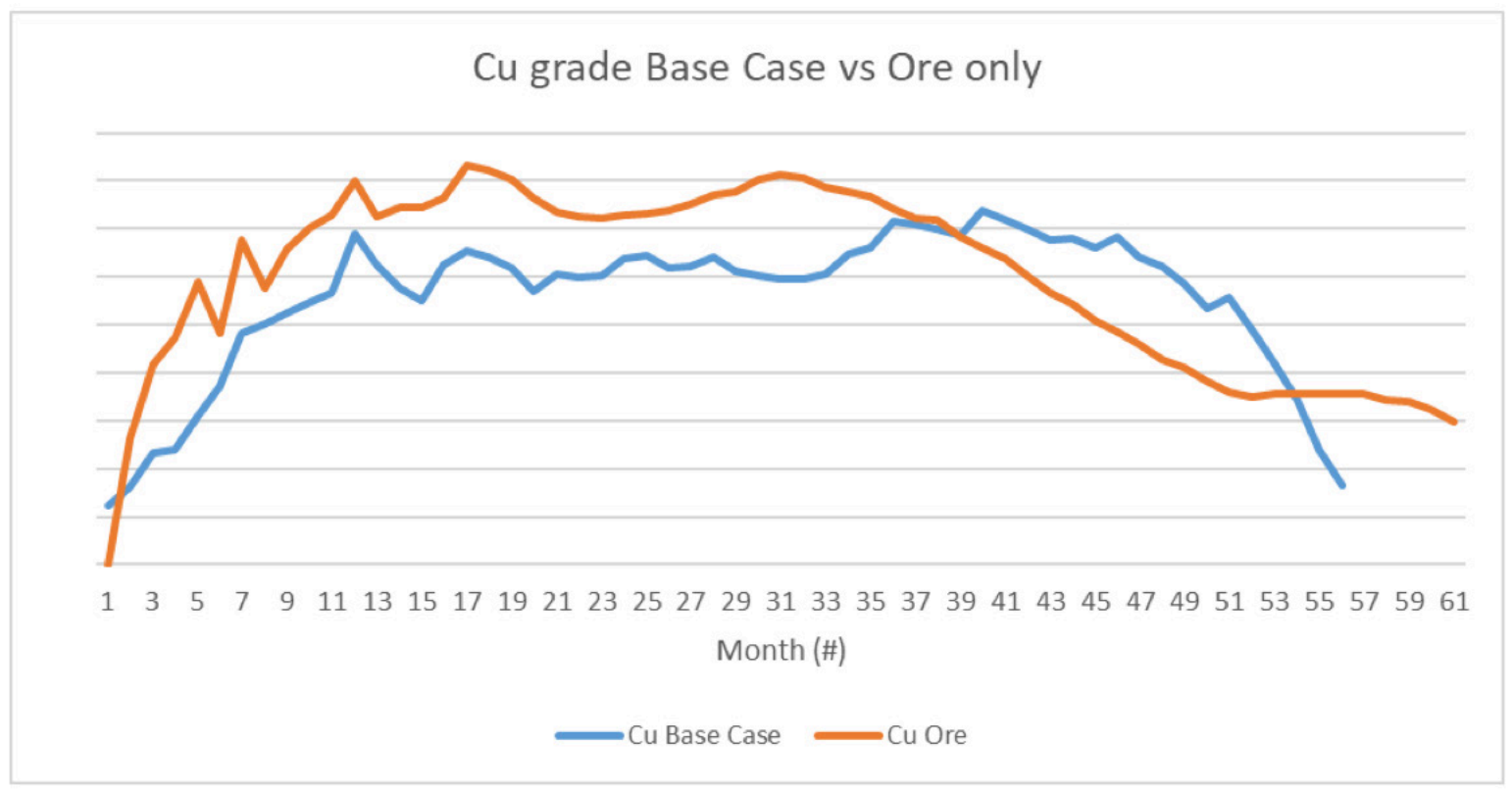

\section{Figure 19 Cu grade comparing the base case and separate ore/dilution handling}

\section{$4 \quad$ Conclusions}

Inclined caving is a feasible and economically viable alternative for the Papomono mine. It provides a stronger layout and more effective ground support, minimising the volume of excavations inside the orebody, mainly at the PPM Fault. The ore zone shape and grade distribution required a more flexible layout and better drawpoint distribution.

Using the PCBC model, this deposit could be modelled in detail and all the information and inputs could be managed effectively per drawpoint, providing sufficient flexibility and level of detail to create a robust base case. In addition, an option to improve the economic results by handling ore and waste separately was modelled with encouraging results.

\section{References}

Carew, T, 1992, 'Footwall drawpoint caving at Cassiar Mine', Proceedings MassMin 92: Symposium Series, South Africa, pp. 295-301.

Diering, T, 2000, 'PC-BC: A Block Cave Design and Draw Control System', in G Chitombo (ed.), Proceedings of MassMin 2000 , Australian Institute of Mining and Metallurgy, Melbourne, Australia, pp. 469-484.

Fuykschot, J \& Loewen, S, 2016, 'Inclined Caving Option for the DNK Mine, Kazakhstan', in C Carr \& G Chitombo (eds), Proceedings of MassMin 2016, Australia, pp. 669-681.

Hannweg, L, 2004,'Koffiefontein mine front cave - Case History', Proceedings of MassMin 2004, Santiago, Chile, pp. $393-396$.

Jakubec, J \& Laubscher, D, 2012, 'Incline Cave Mining - A Viable Alternative to Horizontal Layout', Proceedings of MassMin 2012, Sudbury, Ontario, Canada.

Jakubec, J, 1992, 'Support at Cassiar underground mine', Proceedings of MassMin 1992, South Africa, pp. 111-123.

Laubscher, D \& Jakubec, J, 2000, 'Block Caving Manual - Incline Cave', ICS 2000 internal document.

Laubscher, D, 1994, 'Cave mining - the state of the art', Journal of The South African Institute of Mining and Metallurgy, South Africa, pp. 279-293.

Minera Tres Valles, 2018, 'NI 43-101 F1 Technical report mineral resource estimate. 
Minera Tres Valles, 2018, Prefeasibility Study (C40012-TV-03-RPT-003).

Mthombeni, C \& Paucar, M, 2004, 'Incline cave: A technical alternative to mine kimberlite deposits at depth', Proceedings of 5th International Conference \& Exhibition on Mass Mining, Chile, pp. 91-95.

Valencia, J, Paredes, P \& Macias, F, 2014, 'La Encantada - An inclined cave design', Proceedings of 3rd International Symposium on Block and Sublevel Caving, Chile, pp. 217-223.

Villa, D, 2016, 'Remnant ore model generation and categorization post block-caving extraction at Salvador mine', in C Carr \& G Chitombo (eds), Proceedings of MassMin 2016, Australia, pp. 461-470.

Villa, D, 2014, 'Mine sequence optimization for Block Caving using the concept of best and worst case' Proceedings of 3rd International Symposium on Block and Sublevel Caving, Chile, pp. 426-436. 